\title{
Sustainable Algae Biodiesel Production in Cold Climates
}

\author{
Rudras Baliga and Susan E. Powers \\ Center for the Environment, Clarkson University, 8 Clarkson Aveue, Potsdam, NY 13699-5700, USA \\ Correspondence should be addressed to Susan E. Powers, sep@clarkson.edu
}

Received 30 November 2009; Accepted 1 April 2010

Academic Editor: Michael K. Danquah

Copyright ( 2010 R. Baliga and S. E. Powers. This is an open access article distributed under the Creative Commons Attribution License, which permits unrestricted use, distribution, and reproduction in any medium, provided the original work is properly cited.

\begin{abstract}
This life cycle assessment aims to determine the most suitable operating conditions for algae biodiesel production in cold climates to minimize energy consumption and environmental impacts. Two hypothetical photobioreactor algae production and biodiesel plants located in Upstate New York (USA) are modeled. The photobioreactor is assumed to be housed within a greenhouse that is located adjacent to a fossil fuel or biomass power plant that can supply waste heat and flue gas containing $\mathrm{CO}_{2}$ as a primary source of carbon. Model results show that the biodiesel areal productivity is high (19 to $25 \mathrm{~L} \mathrm{of} \mathrm{BD} / \mathrm{m}^{2} / \mathrm{yr}$ ). The total life cycle energy consumption was between 15 and $23 \mathrm{MJ} / \mathrm{L}$ of algae BD and $20 \mathrm{MJ} / \mathrm{L}$ of soy BD. Energy consumption and air emissions for algae biodiesel are substantially lower than soy biodiesel when waste heat was utilized. Algae's most substantial contribution is a significant decrease in the petroleum consumed to make the fuel.
\end{abstract}

\section{Introduction}

In 1998, an amendment to the U.S. Energy Policy Act (EP Act) of 1992 triggered the rapid expansion of the US biodiesel industry. This act required that a fraction of new vehicles purchased by federal and state governments be alternative fuel vehicles. The U.S. Energy Independence and Security Act (EISA) of 2007 further mandated the production of renewable fuels to 36 billion gallons (136 billion liters) per year by 2022, including biodiesel. Crops such as soybeans and canola account for more than three quarters of all biodiesel feedstocks in the U.S. [1].

About $14 \%$ of U.S. soybean production and $4 \%$ of global soybean production were used by the U.S. biodiesel industry to produce fuel in 2007 [1]. The use of oil crops for fuel has been criticized because the expansion of biodiesel production in the United States and Europe has coincided with a sharp increase in prices for food grains and vegetable oils [2]. The production of biodiesel from feedstocks that do not use arable land can be accomplished either by using biomass that is currently treated as waste or by introducing a new technology that allows for the development of new feedstocks for biodiesel that utilize land that is unsuitable for food production.
Microalgae have the potential to displace other feedstocks for biodiesel owing to its high vegetable oil content and biomass production rates [3]. The vegetable oil content of algae can vary with growing conditions and species, but has been known to exceed $70 \%$ of the dry weight of algae biomass [4]. Microalgae could have significant social and environmental benefits because they do not compete for arable land with food crops and microalgae cultivation consumes less water than other crops [5]. Algae also grow in saline waters that are unsuitable for agricultural practices or consumption. This makes algae well suited for areas where cultivation of other crops is difficult $[6,7]$. High biomass productivities may be achieved with indoor or outdoor photobioreactors (PBRs) [8]. In cold climates, PBRs have been used successfully, when housed within greenhouses and provided with artificial lighting

Microalgae biodiesel has received much attention in news media. Considerable progress has been made in the field of algae biomorphology [9-11]. In recent decades, however, little quantitative research has been done on the energy and environmental impacts of microalgae biodiesel production on a life cycle basis. The life cycle concept is a cradle to grave systems approach for the study of feedstocks, production, and use. The objective of this work was to assess the feasibility 
TABLE 1: Life cycle sustainability metrics for biodiesel.

\begin{tabular}{|c|c|}
\hline $\begin{array}{l}\text { Environmental } \\
\text { Impact }\end{array}$ & Sustainability Metrics \\
\hline \multirow[t]{5}{*}{$\begin{array}{l}\text { Energy and Resource } \\
\text { Consumption }\end{array}$} & - Total energy consumed (MJ/L BD) \\
\hline & $\begin{array}{l}\text { - Fossil fuel energy consumed } \\
(\mathrm{MJ} / \mathrm{L} \mathrm{BD})\end{array}$ \\
\hline & - Petroleum consumed (MJ/L BD) \\
\hline & - Land required $\left(\mathrm{m}^{2} / \mathrm{L}\right.$ of $\left.\mathrm{BD}\right)$ \\
\hline & - Water required (L water/L BD) \\
\hline Climate Change & $\begin{array}{l}\text { - Net green house gas emissions } \\
\left.\text { ( } \mathrm{g} \mathrm{CO}_{2} \text { equivalents/L of } \mathrm{BD}\right)\end{array}$ \\
\hline Acidification & $\begin{array}{l}\text { - Acidification potential } \\
\text { ( } \mathrm{g} \mathrm{SO}_{2} \text { eq./L BD) }\end{array}$ \\
\hline \multirow[t]{3}{*}{ Toxic Emissions } & $\begin{array}{l}\text { - Particulate matter emissions } \\
\left(\mathrm{PM}_{10}, \mathrm{PM}_{2.5}\right)\end{array}$ \\
\hline & - Carbon monoxide emissions \\
\hline & - Volatile organic carbon emissions \\
\hline
\end{tabular}

of algae biodiesel production in New York State (USA) based on life cycle energy and environmental impact parameters. Upstate NY was chosen as a challenging case for algae biodiesel production due to shorter days and cold temperatures during winter months. The productivity, energy consumption, and environmental emissions associated with the algae/BD production lifecycle were quantified in order to identify the best growing conditions and assess its impacts relative to soybean biodiesel.

\section{Methodology}

2.1. System Boundary and Scope. The life cycle concept is a cradle to grave systems approach for the study of feedstocks, production, and use. The concept revolves around the recognition of different stages of production starting from upstream use of energy to cultivation of the feedstock, followed by the different processing stages. A life cycle inventory assessment allows for the quantification of mass and energy streams such as energy consumption, material usage, waste production, and generation of coproducts. A summary of the sustainability assessment metrics used for this life cycle inventory of microalgae feedstock for biodiesel production is presented in Table 1 .

Figure 1 provides an overview of the system boundary used in this analysis, which includes the production of algae and biodiesel via a transesterification reaction. The boundary includes all upstream mass and energy flows that are required to make the chemical and energy resources required for the processing. The production of biodiesel from algae and direct energy consumption is characterized by four distinct stages: cultivation, dewatering/drying, oil extraction, and transesterification (Figure 1). The energy consumed and subsequent emissions for fuel production, electricity generation, and chemical production comprise the upstream energy consumption and emissions. Biodiesel and algae meal are the products leaving the system boundary.
The use of these products is not directly included within the analysis.

The hypothetical algae and biodiesel production processing facilities considered are located in upstate placeStateNew York. The facilities are assumed to be adjacent to a biomass or fossil fuel electricity generation plant for access to the carbon dioxide in their flue gas and waste heat in order to maximize the utilization of waste resources within this system. Waste heat is considered to have no value as an energy product; so it is not counted as part of the total energy resources consumed by the facility.

Two different locations were considered for the microalgae biodiesel facility: Syracuse, NY $\left(43^{\circ} 2^{\prime} \mathrm{N}, 76^{\circ} 8^{\prime} \mathrm{W}\right)$ and Albany, $\mathrm{NY}\left(42^{\circ} 7^{\prime} \mathrm{N}, 73^{\circ} 8^{\prime} \mathrm{W}\right)$. Although these locations are at approximately the same latitude and have very similar hours of daylight, the Syracuse area is colder and cloudier throughout the year due to its proximity to the Great Lakes. Albany offers more intense natural lighting and less severe winter temperatures (Figure 2). Three specific cases were considered for each of these locations:

(i) greenhouse structure to maximize natural lighting; natural gas used to maintain the system temperature;

(ii) greenhouse structure to maximize natural lighting; waste heat used to maintain the system temperature;

(iii) a well-insulated facility that allows for no natural lighting but requires substantially less heat.

The PBRs are assumed to operate continuously, using artificial lighting when natural lighting is not sufficient. In all cases, it was assumed that Phaeodactylum tricornutum algae would be grown for biodiesel production. This algae species has a relatively high oil content (about $30 \%$ by dry weight), is resistant to contamination, and has been previously utilized to produce biodiesel $[12,13]$.

Estimating the environmental and energy lifecycle impacts requires quantification of the mass and energy flows through this system. A mathematical model for the algae production process was developed in the work presented here. As shown in Figure 3, the mass and energy flows estimated with the algae production model were used in conjunction with the Greenhouse gases, Related Emissions, and Energy use in Transportation (GREET) model 1.8a developed at the Argonne National Laboratories [14]. GREET provided the general framework and structure for the lifecycle inventory, especially aspects of the transesterification process and energy and emissions related to the upstream production of chemicals and energy resources. BD production from soybeans, which is used here as a benchmark for comparison, was taken directly from the GREET model. GREET is a widely accepted model and many studies and analyses have been based upon it because of its vast data on energy sources and the associated emissions (e.g., [15-17]). The default values for soybean production, oil extraction, and transesterification were taken as GREET default values [14], which are representative of the Midwestern region of the United States where most soybeans are grown. These were based initially on an LCA completed at the National Renewable Energy Lab [18] and updated to keep the GREET 


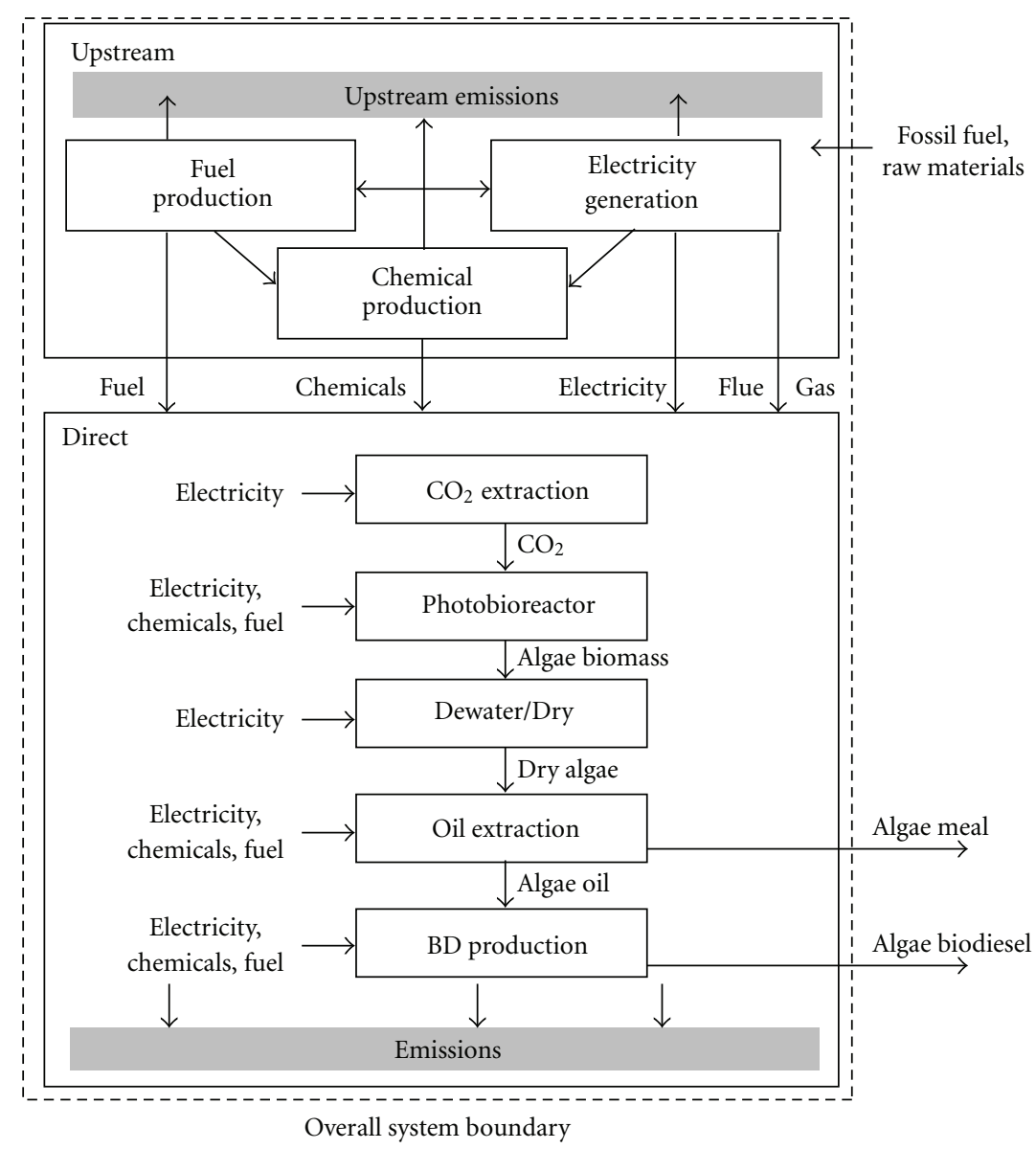

FIGURE 1: Flowchart depicting system boundary for life cycle inventory of biodiesel from microalgae.

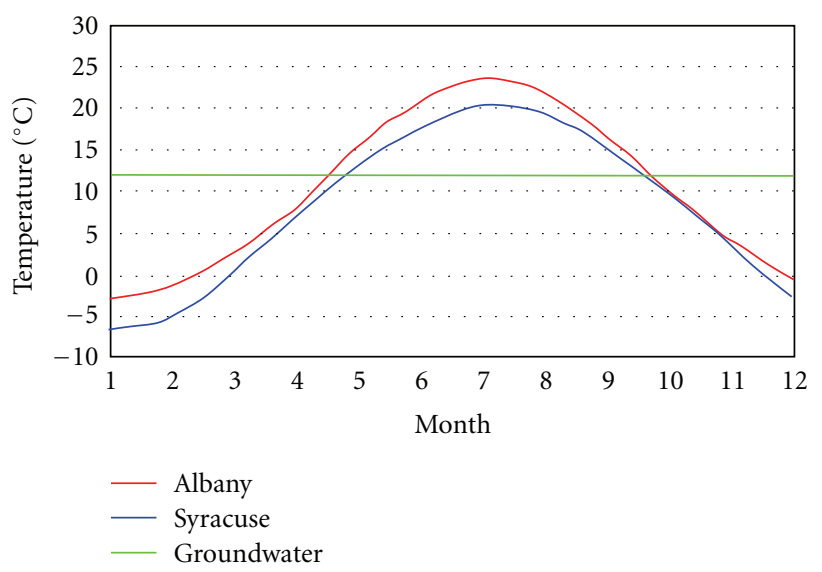

(a)

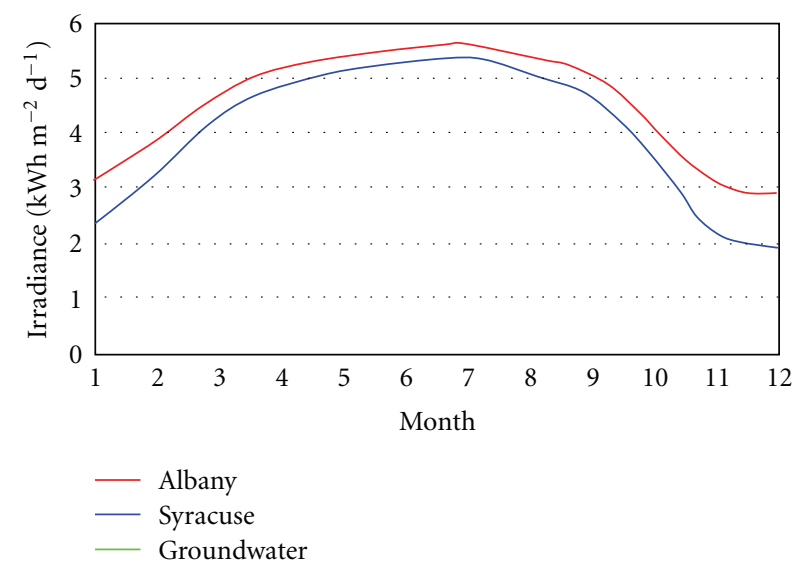

(b)

FIGURE 2: Monthly average temperature (a) and total monthly solar irradiance (b) for Syracuse, NY, and Albany, NY.

model as current as possible (e.g., [17]). There is only a small production of soybeans in NY State, with yields well below the average yield in the Midwest. Thus, no attempt was made to match the geographic system boundaries for biodiesel from algae to that of soybeans.
Uncertainty in the data was addressed by utilizing Monte Carlo simulations to input a range of values for parameters. For a given assumption or variable with a distribution as input, the commercially available software, Crystal Ball was utilized to determine a forecast or range of possible outputs. 


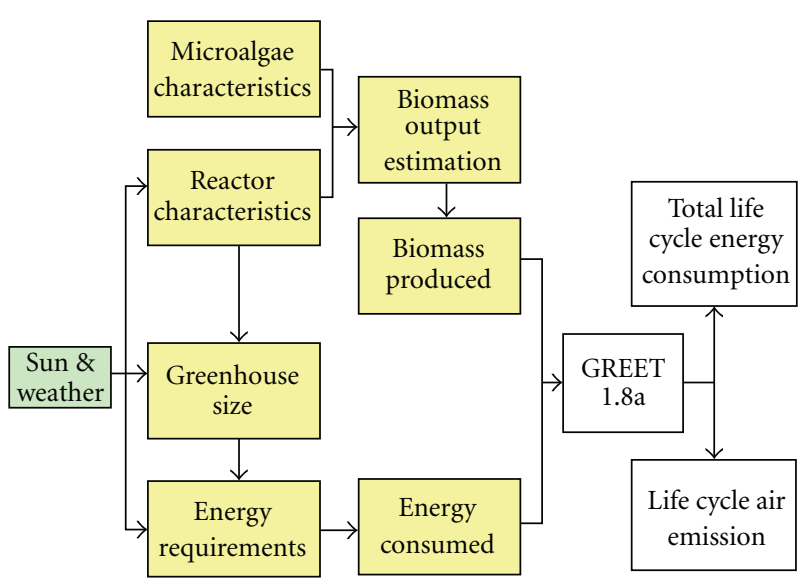

Figure 3: Overview of microalgae biomass LCA model. The yellow boxes represent the contributions of the work presented here. The soybean LCA results were taken almost entirely from GREET.

Standard error bars were created utilizing the mean value of the forecast and 95\% certainty.

2.2. Algae Production Models. The biomass production model utilizes solar data and a biological growth rate to estimate actual yields for algae biomass for a photobioreactor system $[13,19]$.

2.2.1. Microalgae Plant Setup. Hypothetical tubular closed photobioreactors (PBRs) were modeled in this case to predict algae production and account for energy consumption and emissions in Syracuse and Albany NY. The PBR plant setup is illustrated in Figure 4. It was assumed that processes such as dewatering and transesterification could be carried out on site, thus eliminating the need for transportation.

The various dimensions and parameters for the PBR were taken from recommendations of previous studies in order to depict a realistic setup $[12,13]$. The PBR setup was designed for a maximum of 30 hours detention time. The maximum effluent concentration $\left(C_{e}\right)$ was fixed at $3.4 \mathrm{~kg} / \mathrm{m}^{3}$ with a recycle ratio of $0.35[13,20]$ and an allowable superficial fluid velocity of $0.3 \mathrm{~m} / \mathrm{s}$ [21]. Since a long tubular length is required to meet these constraints $(32,400 \mathrm{~m})$, the PBR is split up into 6 units each of which is $61 \mathrm{~m}^{3}(5,400 \mathrm{~m}$ long, $0.12 \mathrm{~m}$ diameter). Stacking of tubes reduces the total foot print area of the greenhouse. All tubes are connected and algae broth passes through all six units.

The floor area or foot print area of the greenhouse house was determined from the volume of the reactor and type of cultivation (annual/seasonal operation) and the specific processes. The diameter of tubes was set at $0.12 \mathrm{~m}$ for all cases since it is a widely reported size for PBRs $[3,13,22,23]$. The spacing of tubes was set at $0.3 \mathrm{~m}$. This is an important factor since it defines the total floor size, which in turn influences heating and lighting requirements. The various parameters related to plant setup are summarized in Table 2 .
2.2.2. Estimating Biomass Output. Microalgae productivity is estimated from the location, reactor specifications, and microalgae data. It is assumed that $\mathrm{CO}_{2}$ and nutrients are provided in excess to the microalgae culture through the media, thereby making light the only limiting factor for cell growth and decay [12]. If adequate lighting is available, the specific growth rate $\mu$ is determined from the average irradiance available $I_{\text {avg }}\left(\mu \mathrm{E} / \mathrm{m}^{2}-\mathrm{s}\right)$ [19]:

$$
\mu=\mu_{\max } \frac{I_{\mathrm{avg}}^{n}}{K_{I}^{n}+I_{\mathrm{avg}}^{n}},
$$

where $K_{I}$ is the half saturation constant (i.e., $I_{\text {avg }}$ for which half of $\mu_{\max }$ is attained), and the exponent $n$ is a unitless empirical constant. Both $K_{I}$ and $n$ are constant for a given species of algae. Note that decay of algae cells during the hours with light is incorporated into the maximum specific growth rate $\left(\mu_{\max }\right)\left(h^{-1}\right)$ since values provided by Molina Grima et al. [22] and Fernandez et al. [23] were determined from the net growth rate. $I_{\text {avg }}$ is determined from the BeerLambert equation:

$$
I_{\mathrm{avg}}=\frac{I}{\varphi_{\mathrm{eq}} K_{a} C_{i}}\left[1-\exp \left(-\varphi_{\mathrm{eq}} K_{a} C_{i}\right)\right],
$$

where $C_{i}\left(\mathrm{~kg} / \mathrm{m}^{3}\right)$ is the influent biomass concentration. The path length of light within the reactor is given by $\varphi_{\text {eq }}$, which is the ratio of the tube diameter to the cosine of the solar zenith angle. The photosynthetically active irradiance (I) $\left(\mu \mathrm{Em}^{-2} \mathrm{~s}^{-1}\right)$ is a function of various solar angles and the total solar irradiance. Hourly solar data were available from NREL's solar database [24], and thus, algae cell growth was determined at an interval of an hour. The analysis of the solar data to estimate $I$ and $\varphi_{\mathrm{eq}}$ is included in the appendix.

The PBR is modeled as a series of plug flow reactors where the effluent concentration of each reactor is the influent concentration for the next. It is assumed that steadystate conditions prevail for each hour since irradiance is taken as a constant over that time period. Utilizing a Monod reaction rate for substrate utilization [22], the resulting steady-state plug flow reactor equation for each segment can be written as

$$
u \frac{d C}{d z}=\mu_{\max } \frac{I_{\mathrm{avg}}^{n}}{K_{I}^{n}+I_{\mathrm{avg}}^{n}} C,
$$

where $C$ is the biomass concentration and $u$ is the fluid velocity. Integrating this expression can provide the effluent concentration for each reactor segment " $j$ " that represents one hour of residence time at an average irradiation rate for that hour:

$$
\ln \left(\frac{C_{j+1}^{k}}{C_{j}^{k}}\right)=\mu_{\max } \frac{\left(I_{\mathrm{avg}(j+1)}^{k}\right)^{n}}{K_{I}^{n}+\left(I_{\mathrm{avg}(j+1)}^{k}\right)^{n}}\left(\frac{L}{u}\right),
$$

where $j$ and $j+1$ indicate the start and end location along the reactor length of the one hour segment. $C_{j+1}$ is calculated in series to determine the reactor effluent concentration, $C_{e}$, for each hour $k$. The growth rate during that hour is defined 


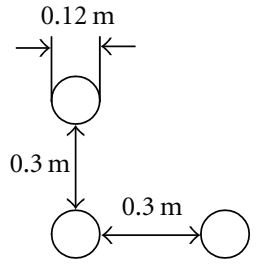

(a) Diameter \& spacing

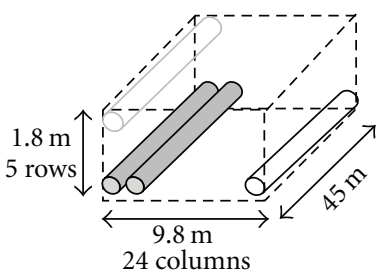

(b) Photobioreactor unit

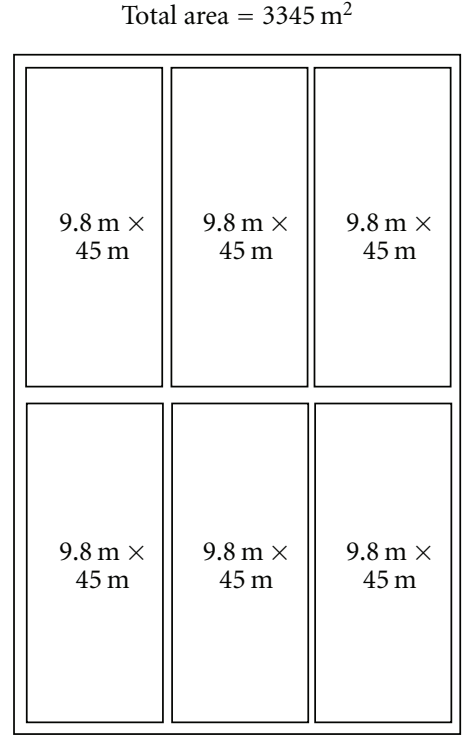

(c) Greenhouse plan

FIgURe 4: Photobioreactor system layout (not to scale).

TABLE 2: Summary of photobioreactor and greenhouse parameters.

\begin{tabular}{|c|c|c|c|}
\hline Parameter & Value & Depends upon & Reference \\
\hline Diameter of tubes & $0.12 \mathrm{~m}$ & Larger diameter pipes can cause cell shading & {$[3]$} \\
\hline Spacing of tubes & 0.3 & Greater spacing is desirable to avoid shading & {$[13]$} \\
\hline Flow rate $(Q)$ & $3.4 \times 10^{-3} \mathrm{~m}^{3} / \mathrm{s}$ & Algae species and tube diameter & {$[21]$} \\
\hline Recycle Ratio $(r)$ & 0.35 & & {$[20]$} \\
\hline Total volume of reactor $(V)$ & $366 \mathrm{~m}^{3}$ & Maximum residence time ( $30 \mathrm{hrs})$ & [12] \\
\hline Influent concentration $\left(C_{i}\right)$ & $1.2 \mathrm{~kg} / \mathrm{m}^{3}$ & & {$[12]$} \\
\hline Max. Effluent concentration $\left(C_{e}\right)$ & $3.4 \mathrm{~kg} / \mathrm{m}^{3}$ & Growth rate, PBR set up & {$[13]$} \\
\hline
\end{tabular}

by the average irradiance for that hour of the day. The total biomass produced per day $\left(M_{\mathrm{BM}}\right)\left(\mathrm{kg} \mathrm{d}^{-1}\right)$ is estimated from the flow rate $(Q)\left(\mathrm{m}^{3} \mathrm{hr}^{-1}\right)$, recycle ratio $(r)$, and the effluent concentration $C_{e}\left(\mathrm{~kg} \mathrm{~m}^{-3}\right)$ :

$$
M_{\mathrm{BM}}=\sum_{k=1}^{24} \mathrm{Q}\left(C_{e}^{k}\right)(1-r) .
$$

The total microalgae biomass produced can be determined from (2), (4), and (5) along with algae growth parameters and solar irradiation data.

The temperature requirements for algae differ by species. In general, faster growing algae species favor higher media temperatures of about $20-30^{\circ} \mathrm{C}[10]$. The algae-related constants used for P. tricornutum in the model are included in Table 3. This species was selected because it has been used in the past to produce microalgae biodiesel and all relevant data were available [22].

2.3. Energy Consumed during Microalgae Cultivation. Cultivating microalgae in closed systems is an energy intensive process, especially in regions with low temperatures and limited natural lighting [13]. The algae growth and harvesting stage involve a large number of intermediate processes for which estimates of the energy consumption were developed here. Energy consumption requirements for extraction and transesterification are already provided in the GREET model [14]. It was assumed that the processes for transesterification of algae oil are identical to that of soy oil. Thus, the chemical (methanol and sodium hydroxide) and energy consumption and the energy and emissions associated with their production were taken directly as the default parameters in GREET.

Water Heating. Energy requirements for a natural gas water heating system were determined by using the specific heat of water and the efficiency rating of the heater as provided by the manufacturer $(\mathrm{EF}=0.82[26])$. It was assumed that groundwater, at an initial temperature $\left(T_{\text {inlet }}\right)$ of $12^{\circ} \mathrm{C}$ [27], would be heated to a thermostat set point $\left(T_{t}\right)$ of $25^{\circ} \mathrm{C}$.

Media Circulation. Electric pumps are used to circulate the media through the entire length of the reactor. The input 
TABLE 3: P. tricornutum growth parameters.

\begin{tabular}{lcc}
\hline Parameter & Value & Reference \\
\hline$\mu_{\max }$ & $0.063\left(\mathrm{~h}^{-1}\right)$ & {$[22]$} \\
$B$ & $0.0018\left(\mathrm{~h}^{-1}\right)$ & {$[25]$} \\
$K_{I}$ & $3426\left(\mu \mathrm{E} \mathrm{m}^{-2} \mathrm{~s}^{-1}\right)$ & {$[22]$} \\
$n$ & $1-1.34$ & {$[25]$} \\
$E_{f}$ & $1.74 \pm 0.09 \mu \mathrm{E} \mathrm{J}^{-1}$ & {$[22]$} \\
$X_{p}$ & $2-4 \%$ & {$[25]$} \\
Oil Content (\%dry weight) & $30 \%$ & {$[13]$} \\
Water Content of algae & $40 \%$ & {$[13]$} \\
Cultivation temperature & $25^{\circ} \mathrm{C}$ & {$[10]$} \\
\hline
\end{tabular}

electrical power required to operate the pumps $\left(P_{p}\right)(\mathrm{W})$ can be given by [28]

$$
P_{p}=\frac{3.91 \times 10^{-6} \mu_{1}^{3} \mathrm{Re}^{2.75}}{\eta_{p} d^{3}} A_{a}, \quad \text { where } \mathrm{Re}=\frac{\rho u d}{\mu_{1}},
$$

where $\mu_{1}\left(\mathrm{~kg} \mathrm{~m}^{-1} \mathrm{~s}^{-1}\right)$ is the dynamic viscosity of water, Re is the Reynolds number, $d(\mathrm{~m})$ is the diameter of the pipes, $u$ is the superficial velocity of flow $(\mathrm{m} / \mathrm{s}), \eta_{p}$ and $\eta_{\text {elec }}$ are the pump efficiency $\left(\eta_{p}=0.7\right)$, and $A_{a}\left(\mathrm{~m}^{2}\right)$ is the tube aperture area. The pumps operate continuously.

Artificial Lighting. Natural algae cultivation inherently revolves around the diurnal and seasonal cycles. To compensate for these cycles and to maximize the production of biomass, artificial lighting is used to allow 24-hour cultivation. Lights are turned on from dusk to dawn. Monthly averages of daylight hours are used to define the time the lighting system is in operation each day. The power $\left(P_{a}\right)(\mathrm{W})$ consumed for artificially lighting the greenhouse area is calculated as [29]

$$
P_{a}=A^{\prime}\left(\frac{I_{\mathrm{avg}}}{L_{w} C_{f}}\right) .
$$

The intensity of the artificial lighting provided was set equal to the naturally available lighting in the month of July ( $I_{\text {avg }}$ $\left.=1.7 \mu \mathrm{E} / \mathrm{m}^{2}-\mathrm{s}\right)$ over the entire greenhouse region $\left(A^{\prime}=\right.$ $3345 \mathrm{~m}^{2}$ ). Specifications for high-efficiency fluorescent GRO lights [29] were used to estimate the power required for artificial lighting. The light intensity of the bulbs is expressed as $L_{w}=220 \mathrm{Lu} / \mathrm{W}$ and the conversion factor $\left(C_{f}\right)$ to convert between micromoles of photons $(\mathrm{mE})$ and lux is 0.29 .

$\mathrm{CO}_{2}$ Purification. Carbon dioxide acts as the only source of carbon for the biomass. Flue gases from power plants provide an inexhaustible source of $\mathrm{CO}_{2}$. However, flue gases also contain varying levels of other gases such as $\mathrm{SO}_{\mathrm{x}}$ and $\mathrm{NO}_{\mathrm{x}}$ which are detrimental to microalgae culture beyond certain concentrations [30]. The monoethanolamine (MEA) absorption process can be used to separate pure $\mathrm{CO}_{2}$ from flue gas for microalgae production. Kadam [31] determined that if about $18 \%$ of the total carbon dioxide consumed is taken directly from flue gases and the rest is purified through the MEA process, then, the toxic flue gases will be sufficiently low concentration for algae growth.

Molina Grima [19] determined that in order to make light the only limiting factor, $\mathrm{CO}_{2}$ must be provided in excess and the ratio of the aqueous $\mathrm{CO}_{2}$ concentration $\left(\mathrm{kg} / \mathrm{m}^{3}\right)$ to influent biomass concentration $C_{i}\left(\mathrm{~kg} / \mathrm{m}^{3}\right)$ should be 0.63 . Since growth rates for this system are lower than those in Molina's Grima study [19] due to reduced sunlight, this $\mathrm{CO}_{2}$ represents a conservative estimate. The mass of carbon dioxide required was estimated based on this ratio, the media flow rate, and the influent biomass concentration. Although carbon dioxide has a high solubility in water, and it is likely that all $\mathrm{CO}_{2}$ in the gas bubbled through the reactor would dissolve over the length of the reactor, a factor of safety of 2 was used here as an overestimate of the mass of $\mathrm{CO}_{2}$ that would be required. The $\mathrm{MEA} \mathrm{CO}_{2}$ extraction process has been modeled and studied previously in context with algae production. Kadam $[31,32]$ reports that the process to extract $\mathrm{CO}_{2}$ from flue gas and recover the MEA for reuse consumes $32.65 \mathrm{kWh}$ per ton of $\mathrm{CO}_{2}$ for algae cultivation. Details are not provided in these references to specifically quantify which of the steps in the MEA process consume the most electrical energy.

Greenhouse Heating. Temperature control within the greenhouse is essential for algae cultivation in cold weather conditions. The energy consumed for greenhouse heating depends upon the total surface area exposed, insulation material, and temperature inside and outside the greenhouse. For a given greenhouse with surface area $\left(A_{g}\right)\left(\mathrm{m}^{2}\right)$ the heat loss per second $\left(Q_{L}\right)(\mathrm{J} / \mathrm{s})$ is given by [33]

$$
Q_{L}=1.05\left(\frac{1}{R}\right)\left(T_{\text {req }}-T_{\text {out }}\right) A_{g}
$$

where $R\left(1.9 \mathrm{~m}^{2}{ }^{\circ} \mathrm{Cs} \mathrm{J}^{-1}\right)$ is the $R$-value of the greenhouse insulating material; $T_{\text {req }}\left(25^{\circ} \mathrm{C}\right)$ and $T_{\text {out }}\left({ }^{\circ} \mathrm{C}\right)$ are the temperatures required within the greenhouse and outside the greenhouse, respectively. The greenhouse was assumed to be insulated with $10 \mathrm{~mm}$ twinwall polycarbonate with an $R$-value of 1.9 . The $R$-value of insulated and windowless cultivation scenario was set at 30 . The outside temperature $T_{\text {out }}$ is taken from monthly averages for Syracuse and Albany and is input as normal distributions for that month [34].

Steam Drying and Dewatering. Algae are suspended in a dilute broth from photobioreactors [13]. Dewatering and drying of algae is necessary to reduce the water content to $5 \%$ [35] before the hexane oil extraction process. For algae with high vegetable oil content, it is suggested that continuous nozzle discharge centrifuges provide the best reliability and consume the least amount of energy. Centrifugation consumes $3.24 \mathrm{MJ} / \mathrm{m}^{3}$ of effluent media [36]. After centrifugation, algae water content is $70 \%$ (by weight).

Steam is utilized to further dry microalgae before oil extraction process. The natural gas consumed to provide the required steam energy was calculated based on the heat of vaporization of water, the mass of water that needed to be vaporized to reduce the water content from 0.70 to 0.05 , and 
the efficiency of the boiler (0.93 [37]) and dryer (0.8 [26]) utilized. In the scenarios that utilize waste heat, it is assumed that because of the colocation of the algae production facility near a power plant, there is sufficient heat to dry the algae.

2.4. Water Consumption. The consumption of water for the production of biofuels has recently been identified as a significant limitation to the development of an expanded biofuel economy. Water consumption occurs almost entirely in the feedstock production step for most biofuels. The average U.S. production biodiesel from soybeans requires 6,500 liters of water for evapotranspiration per liter of biodiesel produced [38]. Water consumption for algae biodiesel was calculated by a mass balance. The total water flowrate through the bioreactor is the sum of freshwater, water included in the algae recycle stream (35\% recycle), and water recovered through the centrifuge dewatering process to increase the algae concentration from $0.34 \%$ to $30 \%$. With this mass balance, $848 \mathrm{~m}^{3}$ make up water is required annually or approximately $4 \mathrm{~L}$ water per $\mathrm{L}$ of biodiesel for the feedstock production stage. This represents approximately $99 \%$ of water recovery and reuse. In the transesterification and biodiesel cleaning processes, $1-3 \mathrm{~L}$ of water are required per L of biodiesel produced [39].

2.5. Fertilizer Consumption. The microalgae culture media acts as the primary source of nutrients and carbon dioxide and a means of expelling excess oxygen. The minimum amount of nutrients consumed was defined based on the molecular formula of algae- $\mathrm{CO}_{0.48} \mathrm{H}_{1.83} \mathrm{~N}_{0.11} \mathrm{P}_{0.01}$ [40]. $\mathrm{N}$ and $\mathrm{P}$ account for $6.5 \%$ and $1.3 \%$ of the algae mass. Assuming that maximum possible biomass concentration of algae cells is $4 \mathrm{~kg} / \mathrm{m}^{3}[13,22]$ in a tubular PBR, the $\mathrm{N}$ and $\mathrm{P}$ consumed from the algae media would be $0.26 \mathrm{~kg} \mathrm{~N} / \mathrm{m}^{3}$ and $0.052 \mathrm{~kg} \mathrm{P} / \mathrm{m}^{3}$. Excess fertilizer that passes through the bioreactor as part of the broth is assumed to be recovered in the centrifuge dewatering step for reuse. Since nearly all of the water is recycled, it is assumed that nearly all of the nutrients that are not consumed are also recycled.

\subsection{Utilizing GREET for Life Cycle Analysis. The GREET} model was modified and used to calculate the energy use and emissions generated from algae production, oil extraction, and transesterification stages of biodiesel production as well as the upstream chemical and energy production processes. For a given fuel system GREET evaluates natural gas, coal, and petroleum use as well as the emissions of carbon dioxide equivalent greenhouse gases, volatile organic compounds, carbon monoxide, nitrogen oxides, particulates, and sulfur oxides from all lifecycle stages [14]. The GREET results are presented as primary energy consumed and emissions per million BTU fuel produced. The low heating value of the BD was used to convert to the functional unit used here-liters $\mathrm{BD}$ produced.

The GREET model is written in an MS Excel workbook and includes soy biodiesel production energy consumption and emissions pathways. A new spreadsheet page based on the soy biodiesel calculations was added to the GREET workbook and adapted for algae BD production. Default parameters for transesterification were used directly, but other input parameters including energy consumption for the various processes, biomass yield, nutrient requirements, carbon dioxide consumed were modified for algae biodiesel production based on the mass and energy flows presented above. The mix of electricity generation within New York State was used to define the primary energy consumed to generate electricity [41].

The extraction of oil from algae was assumed to be carried out by hexane oil extraction. The procedure is similar to soybean oil extraction, although significantly less hexane is required to recover oil from algae $(0.030 \mathrm{~kg}$ of hexane $/ \mathrm{kg}$ of dry algae) [11] than is required for soybeans $(1.2 \mathrm{~kg}$ hexane/kg dried and flaked soy bean) [18]. During this process, algae meal is produced as a coproduct that can be used as an animal feed in the same manner that soy meal is used as a coproduct from soy biodiesel. GREET uses the displacement method to determine how much of the biomass production and extraction steps can defined as a credit for the biodiesel due to the production of a coproduct. The protein content of soy meal is $48 \%$ [ 42 ], as compared to $28 \%$ in algae meal [13] and $40 \%$ in soy beans [42]. Thus, $1 \mathrm{~kg}$ of algae meal displaces about $0.7 \mathrm{~kg}$ of soybean, whereas $1 \mathrm{~kg}$ of soy meal displaces about $1.2 \mathrm{~kg}$ of soy bean for animal feed. The credits for not having to produce $0.7 \mathrm{~kg}$ soy beans for every $\mathrm{kg}$ algae meal produced are subtracted from the total energy use and emissions associated with the algae production, oil extraction, and their associated upstream processes.

An additional credit was also attributed to the algae to represent the carbon dioxide sequestered from the power plant flue gas. Algae cell elemental composition was used to estimate the mass of carbon that was consumed by the algae growth within the PBR $\left(0.51 \mathrm{~kg}\right.$ of $\mathrm{CO}_{2}$ consumed $/ \mathrm{kg}$ algae grown).

\section{Results}

3.1. Biomass Production. Biomass output is an important factor for determining life cycle energy analysis of microalgae biodiesel production. When natural lighting is used to minimize electricity consumption for artificial lighting, algae production rises steadily between the months of February and April (Figure 5). Biomass production is the highest between the months of May to July and is followed by a gradual decline in the months of August to October. Production is the lowest in the winter months due to low natural irradiance. The uncertainty bars included represent 95\% confidence intervals from Monte Carlo simulation outputs.

The annual biomass productivity in Albany is about 12\% greater than that in Syracuse (Table 4). These cities are at very similar latitudes, but the actual irradiance in Albany is higher due to less cloud cover. Biomass and subsequent biodiesel production in the windowless (artificial lighting only) scenario is much higher than greenhouse cases because 
TABLE 4: Comparison of different locations and scenarios by biodiesel production.

\begin{tabular}{|c|c|c|c|}
\hline Location & Biomass Produced & (tonnes/year) & Biodiesel produced $\left(\mathrm{L} \mathrm{m}^{-2} \mathrm{y}^{-1}\right)$ \\
\hline \multirow{2}{*}{ Syracuse NY } & Greenhouse Base Case & 202 & 19 \\
\hline & Greenhouse w/waste heat & 202 & 19 \\
\hline \multirow{3}{*}{ Albany NY } & Windowless Cultivation & 263 & 25 \\
\hline & Greenhouse Base Case & 225 & 21 \\
\hline & Greenhouse w/waste heat & 225 & 21 \\
\hline
\end{tabular}

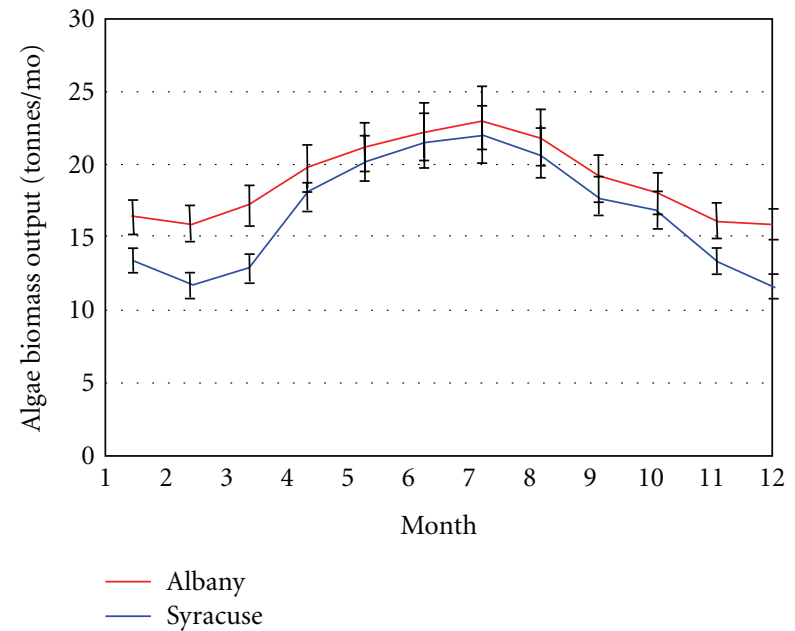

Figure 5: Algae Biomass production for Syracuse and Albany, NY, with natural lighting supplemented by artificial lighting for continuous algae production.

illumination is maintained throughout the year at the highest level achieved naturally (noon in the month of July).

\subsection{Energy Consumption for Microalgae Biodiesel Produc-} tion. The energy consumed for biodiesel production was estimated by modeling individual processes in the algae cultivation stage. Energy required for the transesterification process is accounted directly by the GREET $1.8 \mathrm{a}$ model. The energy required for feedstock production through the drying process is illustrated in Figure 6. This does not include oil extraction and transesterification processes. Three variables can be assessed with this graph: location (Syracuse versus Albany), use of natural lighting versus solely artificial lighting and algae versus soybean production.

Heating needs consume well over half of the total energy required for algae growth, dewatering, and drying. When no waste heat is available, dewatering and steam drying accounts for the greatest fraction-about 28-32\% of the energy required for feedstock production. With the availability of waste heat, this component is reduced to about $13 \%$ of the total, which represents the electricity required for centrifugation. Greenhouse heating consumes a similar proportion of the total energy for algae productionabout 25-30\%. Water heating for cultivation consumes about $7-12 \%$ for feedstock production. Both locations have

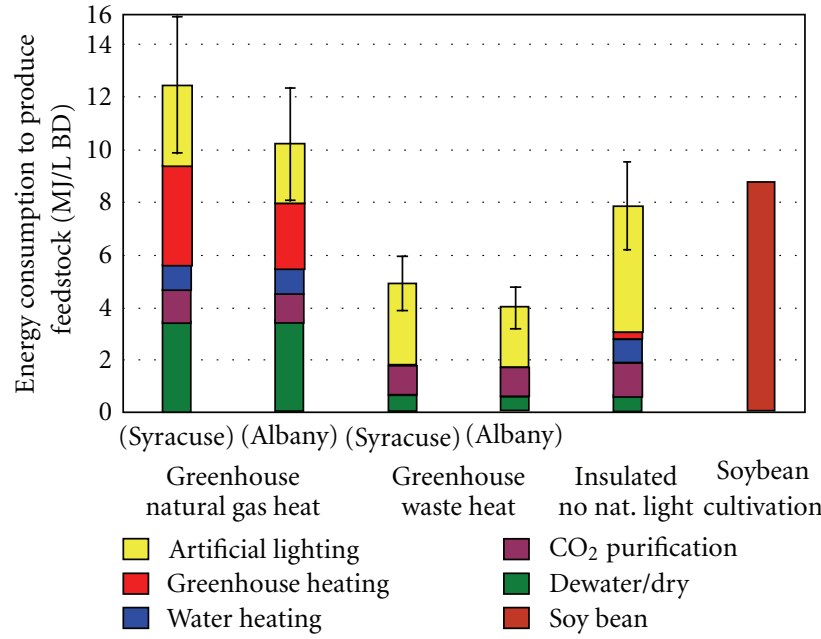

Figure 6: Energy consumption for microalgae and soy bean feedstock production. The error bars represent 95\% confidence intervals on the total energy consumption for feedstock production.

similar water heating requirements because groundwater temperature is assumed to be equal for both cases.

When natural lighting is utilized to the extent possible artificial lighting, it consumes about a quarter of the total energy required for algae cultivation. However, in the windowless cultivation case where there is no natural light available, the artificial lighting cost is almost doubled. However, the total energy requirements in this scenario are still less $(35 \%)$ than the scenarios requiring natural gas to heat a greenhouse.

Among the design choices and trade-offs considered here, the growth and drying of algae with the utilization of waste heat is the only scenario that is substantially better than growing soybeans from the perspective of process energy consumed. These results clearly show the value of colocating an algae facility near a source of waste heat.

Overall, microalgae cultivation in Albany, NY, consumes about 18-21\% less energy than Syracuse, NY, because greenhouse heating energy requirements are lower and higher natural lighting intensity yields about $12 \%$ higher biomass output.

Figure 7 illustrates the total lifecycle energy, which now also includes biodiesel production and credits for $\mathrm{CO}_{2}$ consumption and algae/soy meal produced during the oil extraction phase. For most cases, the energy required for feedstock production is similar to the energy required for oil 


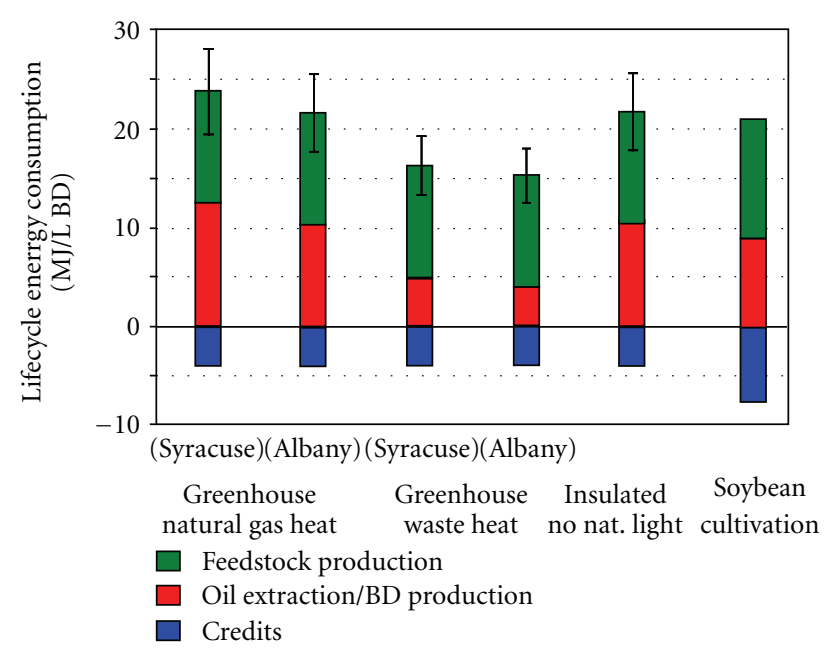

Figure 7: Total life cycle energy consumption by life cycle stage. The error bars represent $95 \%$ confidence intervals on the total lifecycle energy consumed.

extraction and transesterification. Thus, the savings associated with the utilization of waste heat in the greenhouse also represent significant savings when the entire lifecycle energy consumption is considered. Greenhouse algae cultivation with waste heat in Albany consumes the least energy on a life cycle basis; however total energy consumption is very similar to that of the corresponding Syracuse case.

The importance of the coproduct and carbon dioxide consumption credits are apparent from the data presented in Figure 7. Soy meal credits are higher than algae meal credits because of higher protein content and higher fraction of soy meal produced per liter of biodiesel $(1 \mathrm{~kg}$ of algae meal displaces about $0.7 \mathrm{~kg}$ of soybean, whereas $1 \mathrm{~kg}$ of soy meal displaces about $1.2 \mathrm{~kg}$ of soy bean for animal feed). Adding the higher credits for the soy bean $\mathrm{BD}$ case to the energy required for production reduces the net energy for this case to a level below the well-insulated and windowless algae production scenario. The greenhouse scenarios utilizing waste heat are still the best option for minimizing the consumption of energy that has value for other uses.

Natural gas accounts for $65-80 \%$ of the total energy consumed on a life cycle basis for algae biodiesel production when waste heat is not available (data not shown). The high consumption of natural gas can be attributed to heating processes, the high fraction of natural gas in NY electricity mix (about 22\%), and upstream consumption for process fuel and fertilizer production. In contrast, soy biodiesel requires substantially more petroleum $(\sim 5 \mathrm{x})$ than microalgae consumes due to the extensive use of tractors and feedstock transportation when $\mathrm{BD}$ is made from soybeans. Thus, algae as a BD feedstock has a significant benefit over soybeans in terms of reducing our dependence on imported oil. Algae biodiesel production requires a significant amount of electricity and thus coal accounts for about $6-19 \%$ of the total life cycle energy consumption. Insulated cultivation has the highest coal consumption, about $19 \%$ of the total life cycle energy consumption, because of increased artificial

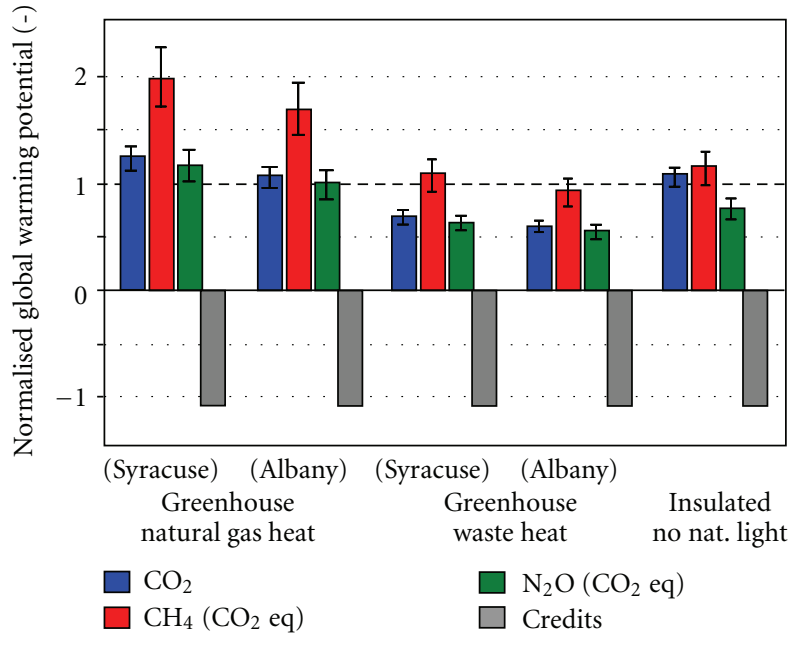

FIGURE 8: Global warming potential of microalgae biodiesel-mass emissions normalized by dividing by the corresponding emissions for soy biodiesel for comparison.

lighting and electricity consumption. In comparison, for the greenhouse with waste heat case, only $7 \%$ the total lifecycle energy is derived from coal.

The processing of soybeans to prepare for oil extraction also requires some heating to dry the beans. Arguably, waste heat could be considered to reduce the fossil fuel consumption for soybean biodiesel too. However, whereas the algae feedstock could be grown at the same location where waste heat is available, the soybeans require a much more dispersed geographical region. Soybeans are typically transported 75 miles or less to a soybean crushing facility. Thus, the probability that soybean production and crushing facilities can be colocated with a waste heat source is significantly less than for algae. If this can be achieved, the lifecycle energy production for the feedstock production (green bar for soybean BD, Figure 7) would be less.

3.3. Global Warming Potential. Global warming potential can be described as the impact of additional units of greenhouse gases to the atmosphere. The global warming potential for the different scenarios and gases is estimated in terms of carbon dioxide equivalents (Figure 8). All algae scenarios are allocated the same $\mathrm{CO}_{2}$ credits because the carbon dioxide consumed per unit of algae produced is constant.

Most $\mathrm{CO}_{2}$ emissions for algae biodiesel originate from upstream usage of energy use for heating, transportation fuel use, and coal combustion for electricity. The extraction and utilization of natural gas for heating use, electricity generation, and fertilizer production is accompanied by high methane emissions. Natural gas extraction has a very high methane emission factor. Overall, the emission of carbon dioxide is relatively low compared to methane due to the high natural gas use relative to petroleum or coal. Natural gas utilization has a much lower carbon dioxide emission factor than coal. 


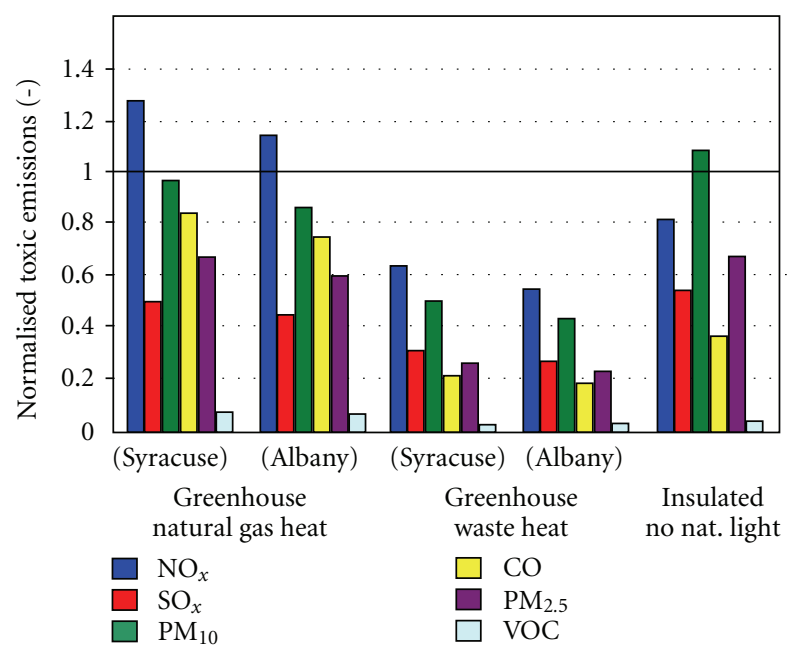

Figure 9: Toxic air emissions from microalgae biodiesel production-mass emissions normalized by dividing by the corresponding emissions for soy biodiesel for comparison.

In cold climates, the production of algae biodiesel with the utilization of waste heat rather than natural gas consumption is the only approach that reduces greenhouse gas emissions relative to soy biodiesel.

3.4. Other Air Emissions. The exposure of humans to air pollutants is increasingly associated with increased mortality and reduction in life expectancy [43]. Figure 9 presents the lifecycle air emissions for algae biodiesel production normalized to the corresponding air emissions estimated by GREET for soybean biodiesel. The microalgae biodiesel air emissions follow a trend similar to the total life cycle energy consumption. The high $\mathrm{NO}_{x}$ emissions can be traced to high emission factors of equipment used to produce natural gas and the flaring of natural gas in refineries. The increased use of artificial lighting for the cultivation of algae in a windowless and well-insulated facility results in high particulate emissions, particularly in comparison to cases where natural lighting is used. These PM emissions originate mainly from coal and residual oil combustion use for electricity production.

VOC emissions from microalgae biodiesel production are much lower than soy biodiesel, because of low utilization of petroleum and hexane. The VOC emission factors for transportation fuels like gasoline are far greater than any other source. Thus, since algae is locally produced for biodiesel and transportation minimal, the VOC emissions from algae biodiesel are much less than soy biodiesel, primarily because only a minimal amount of hexane is required for extraction compared with soy beans.

Overall, the most important source of air emissions for microalgae is the upstream emissions associated with fuel and electricity generation. Yet, these emissions are still relatively low compared to soy biodiesel. The primary factor contributing to this apparent anomaly is the comparison of algae biodiesel produced in New York State to soy biodiesel produced nationally. NY State has a high percentage of hydroelectric (17\%) and nuclear (29\%) power production and relatively small amounts of electricity generated from coal (15\%) [41]. This difference in upstream electricity generation has significant repercussions throughout the lifecycle energy emission estimates for any electricity-intensive manufacturing system: manufacturing in New York State benefits from relatively clean energy resources.

The acidification of soils and water bodies occurs mainly due to the transformation of gaseous pollutants $\left(\mathrm{SO}_{x}, \mathrm{NO}_{x}\right)$ into acids. The acidification potential of the different cases is estimated in $\mathrm{SO}_{2}$ equivalents. All cases of microalgae biodiesel are better than soy biodiesel in terms of acidification emissions. The total $\mathrm{SO}_{2}$ equivalents follow a trend that resembles the total energy usage.

3.5. Summary of Results. A summary of the lifecycle sustainability assessment metrics for the various algae biodiesel production scenarios and soy biodiesel production is presented in Table 5. The most sustainable biodiesel production for all cases requires the colocation of the algae and BD production facility in the vicinity of a source of waste heat. "Free" heat greatly reduces the fossil fuel consumption and all related green house gas and other air pollutants. At a similar latitude, choosing a location that maximizes sunlight helps somewhat to increase the algae production rate and, therefore, reduce the impacts when the results are compared on a per BD-produced basis. These effects are small, however, compared to the benefits of utilizing waste heat. Similarly, a well-insulated facility can help reduce heating needs, but the consequences of increased electricity use for artificial lighting decrease the benefits of reduced heating fuel required. In most regions of the U.S., where a higher fraction of the electricity mix is generated from fossil fuels, the well insulated windowless scenario would be worse in terms of most sustainability metrics due to the increased dependence on fossil fuels.

\section{Conclusions}

Cultivation of microalgae in NY State is an energy intensive process owing to temperature control and steam drying process. Colocating microalgae cultivation with a power plant is highly desirable. Annual production of microalgae requires the utilization of waste heat for steam drying, water heating, and greenhouse heating in order to be substantially better than soy biodiesel in terms of energy consumption and emissions. When waste heat is utilized, microalgae biodiesel production consumes less energy than soy biodiesel.

Microalgae consumes less than one third the petroleum fossil fuel required for soy biodiesel and only a small fraction of the water. The feasibility of microalgae biodiesel production at a given location is greatly dependent on availability of waste heat and natural lighting conditions. The availability of either one or both makes algae biodiesel production process cleaner in terms of air emissions and consumes much less energy than soy biodiesel. However if both natural 
TABLE 5: Summary of average sustainability metrics to compare algae and soy BD production.

\begin{tabular}{|c|c|c|c|c|c|c|c|}
\hline \multirow{2}{*}{\multicolumn{2}{|c|}{ Environmental Impact }} & \multicolumn{6}{|c|}{ Scenario } \\
\hline & & $\begin{array}{c}\text { Greenhouse } \\
\text { Nat. Gas, } \\
\text { Syracuse }\end{array}$ & $\begin{array}{c}\text { Greenhouse } \\
\text { Nat. Gas, } \\
\text { Albany }\end{array}$ & $\begin{array}{c}\text { Greenhouse } \\
\text { w/waste heat, } \\
\text { Syracuse }\end{array}$ & $\begin{array}{c}\text { Greenhouse } \\
\text { w/waste heat, } \\
\text { Albany }\end{array}$ & $\begin{array}{l}\text { Insulated, } \\
\text { no nat. } \\
\text { light }\end{array}$ & $\begin{array}{l}\text { Soy biodiesel } \\
\text { production }\end{array}$ \\
\hline \multicolumn{2}{|c|}{$\begin{array}{l}\text { Total life cycle energy } \\
\text { Consumption* (MJ/L of BD) }\end{array}$} & 23 & 21 & 16 & 15 & 22 & 21 \\
\hline \multicolumn{2}{|c|}{ Land utilization $\left(\mathrm{m}^{2} / \mathrm{L}\right.$ of $\left.\mathrm{BD} / \mathrm{yr}\right)$} & 0.053 & 0.048 & 0.053 & 0.048 & 0.040 & 22.2 \\
\hline \multicolumn{2}{|c|}{ Water Consumption (L water/L BD) } & $5-7$ & $5-7$ & $5-7$ & $5-7$ & $4-6$ & 6,500 \\
\hline \multicolumn{2}{|c|}{$\begin{array}{l}\text { Greenhouse gas emissions } \\
\left(\mathrm{g} \mathrm{CO}_{2} \text { equiv/L of } \mathrm{BD}\right)\end{array}$} & 1350 & 1150 & 740 & 630 & 910 & 925 \\
\hline \multicolumn{2}{|c|}{$\begin{array}{l}\text { Acidification potential } \\
\left.\text { ( } \mathrm{g} \mathrm{SO}_{2} \text { eq./L of } \mathrm{BD}\right)\end{array}$} & 4.9 & 4.6 & 2.8 & 2.5 & 3.4 & 4.0 \\
\hline \multirow{4}{*}{$\begin{array}{l}\text { Toxic Emissions } \\
(\mathrm{g} / \mathrm{L} \text { of } \mathrm{BD})\end{array}$} & PM 10 & 5.1 & 4.6 & 2.6 & 2.3 & 5.7 & 5.3 \\
\hline & PM 2.5 & 1.8 & 1.6 & 0.7 & 0.6 & 1.8 & 2.7 \\
\hline & VOC & 0.22 & 0.20 & 0.06 & 0.05 & 0.09 & 3.4 \\
\hline & $\mathrm{CO}$ & 2.4 & 2.1 & 0.6 & 0.5 & 1.0 & 2.8 \\
\hline
\end{tabular}

* does not include credits.

lighting and waste heat are absent, algae biodiesel production consumes more energy than soy biodiesel production and emits an equal or more amount toxic air emissions.

Coproducts produced during algae biodiesel production process have less protein content than soy meal and, thus, are less valuable. The production of high value coproducts allows for increased energy allocation for soy biodiesel and thus emissions or energy consumption of both the feedstocks is very close and comparable.

Most microalgae biodiesel production scenarios have low or very similar emissions as compared to soy biodiesel. Green house gas emissions for algae biodiesel are generally higher than soy biodiesel except when waste heat is utilized, in which case emissions are equal. The emission of volatile organic compounds for soy biodiesel is much higher than that for algae biodiesel. Emissions from microalgae production originate mainly from upstream fossil fuel energy consumption. Reducing needs for unit processes like greenhouse heating, lighting, and other systems will have significant benefits.

\section{Appendix}

\section{Estimation of Average Light Intensity}

A model is used to estimate the growth rate as a function of light for a geographic location and day of the year for tubular photobioreactors [12] that takes into account various solar angles, cloudiness, and reactor geometry. The model accounts for weather conditions and relates them to the growth of biomass.

The photosynthetically active irradiance $(I)\left(\mu \mathrm{Em}^{-2} \mathrm{~s}^{-1}\right)$ used in (2) is a function of various solar angles $\left(\omega, \omega_{s}\right)$, total solar irradiance $(H)\left(\mathrm{J} \mathrm{m}^{-2} \mathrm{~d}^{-1}\right)$, and photosynthetic efficiency $\left(E_{f}\right)\left(\mu \mathrm{EJ}^{-1}\right)$. The total photosynthetically active irradiance $(I)$ over a horizontal culture surface can be determined from the total solar irradiance $(H)$
$\left(\mathrm{kWhm}^{-2} \mathrm{~d}^{-1}\right)$ directly by utilizing the following equation $[22,44]$ :

$$
I=\frac{\pi H E_{f}}{24}(a+b \cos \omega)\left|\left(\frac{\cos \omega\left(\cos \omega_{s}\right)}{\sin \omega_{s}-\omega_{s}\left(\cos \omega_{s}\right)}\right)\right|,
$$

where

$$
\begin{aligned}
& a=0.409+0.502 \sin \left(\omega_{s}-60\right), \\
& b=0.661+0.477 \sin \left(\omega_{s}-60\right) .
\end{aligned}
$$

The photosynthetic efficiency $\left(E_{f}\right)$ is the ratio of the photosynthetically active radiation to the total incident radiation $(H)$. $E_{f}$ for $P$. tricornutum algae varies as (1.74 $\left.\pm 0.09 \times 10^{-6} \mathrm{EJ}^{-1}\right)$ [22]. It is substituted as a normal distribution with mean $1.74 \times 10^{-6}$ and standard deviation $0.09 \times 10^{-6}$ for Monte Carlo simulations.

The total extraterrestrial irradiance incident on the earth $\left(H_{o}\right)\left(\mathrm{kWh} \mathrm{m}^{-2} \mathrm{~d}^{-1}\right)$ varies seasonally. Some of the incoming solar irradiance is lost due to varying atmospheric transmissivity $\left(K_{h}\right)$ associated with cloud cover. The atmospheric transmissivity, which is also known as the clearness index, is the ratio of the total daily radiation $(H)\left(\mathrm{kWh} \mathrm{m}^{-2} \mathrm{~d}^{-1}\right)$ at ground level to the total daily extraterrestrial radiation $\left(H_{o}\right)$ $\left(\mathrm{kWh} \mathrm{m}^{-2} \mathrm{~d}^{-1}\right) . K_{h}$, a unitless parameter, varies by month. For this study, NREL's solar data [24] were used as monthly averages for $H_{o}$ and $K_{h}$ values [24]. The total irradiance incident that makes it to the earth surface $(\mathrm{H})$ surface was calculated as the product of $H_{o}$ and $K_{h}$. Values for $\mathrm{H}$ in Syracuse NY are shown in Figure 10.

Seasonal variations in solar irradiance may be attributed to changes in the solar declination angle. The solar declination angle varies throughout the year and is a function of the day number of the year $(N) . N$ takes on values from 1 (January 1 ) to 365 . The solar declination angle $(\delta)$ is constant 


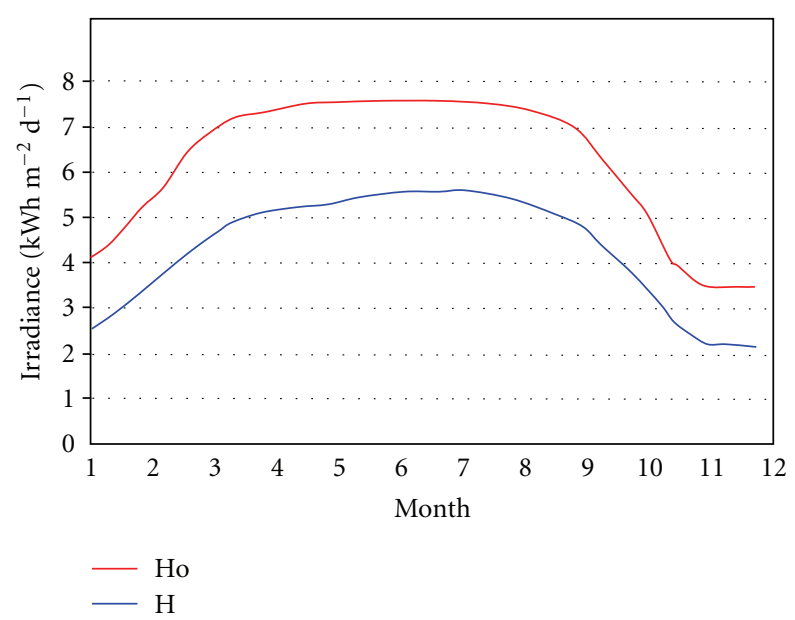

FIgURE 10: Solar irradiance for Syracuse, NY.

for all locations in the northern hemisphere and can be calculated for each day as follows [45]

$$
\delta=23.45 \sin \left(\frac{360}{365}(284+N)\right)
$$

Note. $23.45^{\circ}$ is the angle at which the axis of the earth is tilted and $360^{\circ}$ and 284 are conversion factors from radians to degree. 365 denotes the number of days taken to complete one revolution by the earth around the sun.

The solar angle at sunrise $\left(\omega_{s}\right)$ incorporates seasonal variations in solar declination angle with the latitude $(\Phi)$ (degrees) of the area being considered:

$$
\cos \omega_{s}=-(\tan \delta)(\tan \Phi) .
$$

The solar hour angle $(\omega)$ (degrees) for a location on earth is zero when the sun is directly overhead and negative before noon and positive in the afternoon [46]. Similarly, hourly changes in the solar irradiance depend upon solar hour angle $(\omega)$, which is a function of the solar hour $(h)$. The solar hour $h$ varies from 24 to 1 [43]:

$$
\omega=15(12-h)
$$

Equations (A.2)-(A.4) can be used in conjunction with (A.1a)-(A.1c) to find photosynthetically active irradiance at any given latitude and time.

\section{Acknowledgment}

This work was supported by United States Department of Agriculture Grant no. NRCS-68-3A75-6-512. Publication of this work does not imply endorsement by the funding agency.

\section{References}

[1] DOE Alternative Fuels and Advanced Vehicles Data Center, Biodiesel Production. October, 2009, http://www.afdc .energy.gov/afdc/fuels/biodiesel_production.html.
[2] D. Pimentel, S. Williamson, C. E. Alexander, O. GonzalezPagan, C. Kontak, and S. E. Mulkey, "Reducing energy inputs in the US food system," Human Ecology, vol. 34, no. 4, pp. 459$471,2008$.

[3] C. U. Ugwu, H. Aoyagi, and H. Uchiyama, "Photobioreactors for mass cultivation of algae," Bioresource Technology, vol. 99, no. 10, pp. 4021-4028, 2008.

[4] A. Banerjee, R. Sharma, Y. Chisti, and U. C. Banerjee, "Botryococcus braunii: a renewable source of hydrocarbons and other chemicals," Critical Reviews in Biotechnology, vol. 22, no. 3, pp. 245-279, 2002.

[5] Y. Li, M. Horsman, N. Wu, C. Q. Lan, and N. Dubois-Calero, "Biofuels from microalgae," Biotechnology Progress, vol. 24, no. 4, pp. 815-820, 2008.

[6] E. Ono and J. L. Cuello, "Feasibility assessment of microalgal carbon dioxide sequestration technology with photobioreactor and solar collector," Biosystems Engineering, vol. 95, no. 4, pp. 597-606, 2006.

[7] M. Olaizola, "Commercial development of microalgal biotechnology, from the test tube to the marketplace," Biomolecular Engineering, vol. 20, no. 4-6, pp. 459-466, 2003.

[8] A. Richmond, "Microalgal biotechnology at the turn of the millenniumml: a personal view," Journal of Applied Phycology, vol. 12, no. 3-5, pp. 441-451, 2000.

[9] S. Hirata, M. Hayashitani, M. Taya, and S. Tone, "Carbon dioxide fixation in batch culture of Chlorella sp. using a photobioreactor with a sunlight-collection device," Journal of Fermentation and Bioengineering, vol. 81, no. 5, pp. 470-472, 1996.

[10] J. Sheehan, T. Dunahay, J. Benemannm, and P. Roessler, "A look back at the U.S. Department of Energy's Aquatic Species Program-Biodiesel from Algae," Tech. Rep. TP-580-24190, NREL, Golden, Colo, USA, 1998, http://www.fuelandfiber .com/Athena/biodiesel_from_algae_es.pdf.

[11] H. Xu, X. Miao, and Q. Wu, "High quality biodiesel production from a microalga Chlorella protothecoides by heterotrophic growth in fermenters," Journal of Biotechnology, vol. 126, no. 4, pp. 499-507, 2006.

[12] E. Molina, J. Fernandez, F. G. Acién, and Y. Chisti, "Tubular photobioreactor design for algal cultures," Journal of Biotechnology, vol. 92, no. 2, pp. 113-131, 2001.

[13] Y. Chisti, "Biodiesel from microalgae," Biotechnology Advances, vol. 25, no. 3, pp. 294-306, 2007.

[14] M. Wang, "Overview of GREET model development at Argonne," in Proceedings of the GREET User Workshop, Center for Transportation Research, Argonne National Laboratory, Sacramento, Calif, USA, March 2008, http://www.transportation.anl.gov/pdfs/TA/468.pdf.

[15] A. Lavigne and S. E. Powers, "Evaluating fuel ethanol feedstocks from energy policy perspectives: a comparative energy assessment of corn and corn stover," Energy Policy, vol. 35, no. 11, pp. 5918-5930, 2007.

[16] J. Hill, S. Polasky, E. Nelson, et al., "Climate change and health costs of air emissions from biofuels and gasoline," Proceedings of the National Academy of Sciences of the United States of America, vol. 106, no. 6, pp. 2077-2082, 2009.

[17] CARB, "Detailed California-GREET Pathway for Biodiesel (Esterified Soyoil) from Midwest Soybeans, Ver. 2.1,” Tech. Rep., California Air Resources Board Stationary Source Division, 2009, http://www.arb.ca.gov/fuels/lcfs/022709lcfs_ biodiesel.pdf.

[18] J. Sheehan, V. Camobreco, J. Duffield, M. Graboski, and H. Shapouri, "Life cycle inventory of biodiesel and petroleum 
diesel for use in an urban bus," Tech. Rep. SR-580-24089, NREL, Golden, Colo, USA, 1998.

[19] E. Molina Grima, E.-H. Belarbi, F. G. A. Fernandez, A. R. Medina, and Y. Chisti, "Recovery of microalgal biomass and metabolites: process options and economics," Biotechnology Advances, vol. 20, no. 7-8, pp. 491-515, 2003.

[20] G. L. Rorrer and R. K. Mullikin, "Modeling and simulation of a tubular recycle photobioreactor for macroalgal cell suspension cultures," Chemical Engineering Science, vol. 54, no. 15-16, pp. 3153-3162, 1999.

[21] M. Barbosa, Microalgal photobioreactors: scale up and optimization, Ph.D. Dissertation, van Wageningen University, Wageningen, The Netherlands, 2003.

[22] E. Molina Grima, F. G. A. Fernandez, F. G. Camacho, and Y. Chisti, "Photobioreactors: light regime, mass transfer, and scaleup," Journal of Biotechnology, vol. 70, no. 1-3, pp. 231247, 1999.

[23] F. G. A. Fernandez, F. G. Camacho, J. A. S. Perez, J. M. F. Sevilla, and E. M. Grima, "Modeling of biomass productivity in tubular photobioreactors for microalgal cultures: affects of dilution rate, tube diameter, and solar irradiance," Biotechnology and Bioengineering, vol. 58, no. 6, pp. 605-616, 1998.

[24] National Renewable Energy Laboratory, "National solar radiation database 1991-2005 update: user's manual," Tech. Rep. TP-581-41364, NREL, Golden, Colo, USA, 2007.

[25] L. A. Meireles, A. C. Guedes, C. R. Barbosa, J. L. Azevedo, J. P. Cunha, and F. X. Malcata, "On-line control of light intensity in a microalgal bioreactor using a novel automatic system," Enzyme and Microbial Technology, vol. 42, no. 7, pp. 554-559, 2008.

[26] American Council for Energy Efficient Economy. Water Heating, January 2009, http://www.aceee.org/consumerguide/ waterheating.htm.

[27] Noritz America Corporation. US Average Groundwater Temperature, November, 2008, http://www.noritz.com/u/US_ ground_temperature $\% 5 \mathrm{~B} 1 \% 5 \mathrm{D}$.pdf.

[28] G. Burgess, J. G. Fernandez-Velasco, and K. Lovegrove, "Materials, geometry, and net energy ratio of tubular photobioreactors for microalgal hydrogen production," in Proceedings of the World Hydrogen Energy Conference (WHEC '06), vol. 16, Lyon, France, June 2006.

[29] OSRAM Sylvania Corp, "Photosynthetically Active Radiation Units," October, 2009, http://openwetware.org/images/e/ e8/Conversion_lux.pdf.

[30] M. H. Reddy, Application of algal culture technology for carbon dioxide and flue gas emission control, Master of Science Thesis, Arizona State University, 2002, http://www4.eas.asu.edu/pwest/Theses_Diss/Madhu_Thesis\%20Algae\%20Photosynthesis.pdf.

[31] K. L. Kadam, "Microalgae production from power plant flue gas: environmental implications on a life cycle basis," Tech. Rep. TP-510-29417, National Renewable Energy Laboratory, Golden, Colo, USA, 2001.

[32] K. L. Kadam, "Power plant flue gas as a source of $\mathrm{CO}_{2}$ for microalgae cultivation: economic impact of different process options," Energy Conversion and Management, vol. 38, supplement 1, pp. S505-S510, 1997.

[33] ACF Greenhouses, September, 2008, http://www.littlegreenhouse.com/heat-calc.shtml.

[34] Weather.com, Syracuse monthly average temperatures, November, 2008, http://www.weather.com/wxclimatology/ monthly/graph/13201? from=month_bottomnav_driving.
[35] J. M. Lidell, "Extraction of triglycerides from microorganisms," US Patent no. 6180376, 2001, http://www.patentstorm .us/patents/6180376/description.html.

[36] E. M. Grima, E.-H. Belarbi, F. G. A. Fernandez, A. R. Medina, and Y. Chisti, "Recovery of microalgal biomass and metabolites: process options and economics," Biotechnology Advances, vol. 20, no. 7-8, pp. 491-515, 2003.

[37] S. Sanford, "Greenhouse unit heaters: types, placement, and efficiency,” 2008, http://learningstore.uwex.edu/pdf/A378415.pdf.

[38] R. Dominguez-Faus, S. E. Powers, J. G. Burken, and P. J. Alvarez, "The water footprint of biofuels: a drink or drive issue?" Environmental Science and Technology, vol. 43, no. 9, pp. 3005-3010, 2009.

[39] National Research Council, Water Implications of Biofuels Production in the United States, National Academies Press, Washington, DC, USA, 2008.

[40] J. U. Grobbelaar, "Algal nutrition," in Handbook of Microalgal Culture: Biotechnology and Applied Phycology, A. Richmond, Ed., Blackwell Publishing, Israel, 2004.

[41] DOE Energy Information Agency, New York Electricity Profile, 2007, http://www.eia.doe.gov/cneaf/electricity/st_profiles/ new_york.html.

[42] H. Huo, M. Wang, C. Bloyd, and V. Putsche, "Life-cycle assessment of energy and greenhouse gas effects of soybeanderived biodiesel and renewable fuels," Environmental Science and Technology, vol. 43, no. 3, pp. 750-754, 2008.

[43] Environmental Protection Agency. Health and Environmental Effects of Particulate Matter, December, 2008, http://www.epa.gov/ttncaaa1/naaqsfin/pmhealth.html.

[44] J. A. Duffie and W. A. Beckman, Solar Engineering of Thermal Processes, Wiley, New York, NY, USA, 1980.

[45] B. Y. H. Liu and R. C. Jordan, "The interrelationship and characteristic distribution of direct, diffuse and total solar radiation," Solar Energy, vol. 4, no. 3, pp. 1-19, 1960.

[46] Sunlit Design, Solar Hour Angle, October, 2008, http://www .sunlit-design.com/infosearch/hourangle.php. 

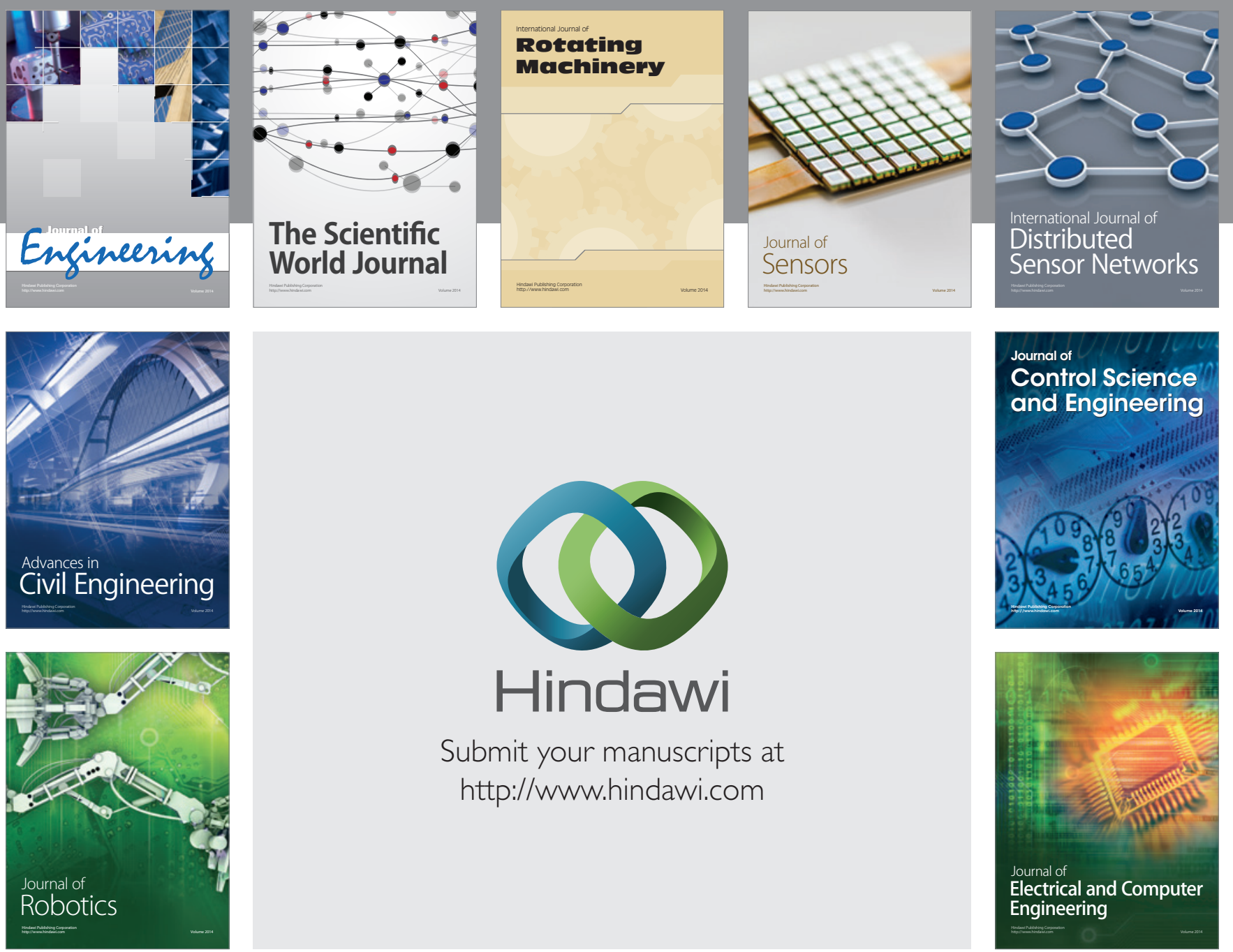

Submit your manuscripts at

http://www.hindawi.com
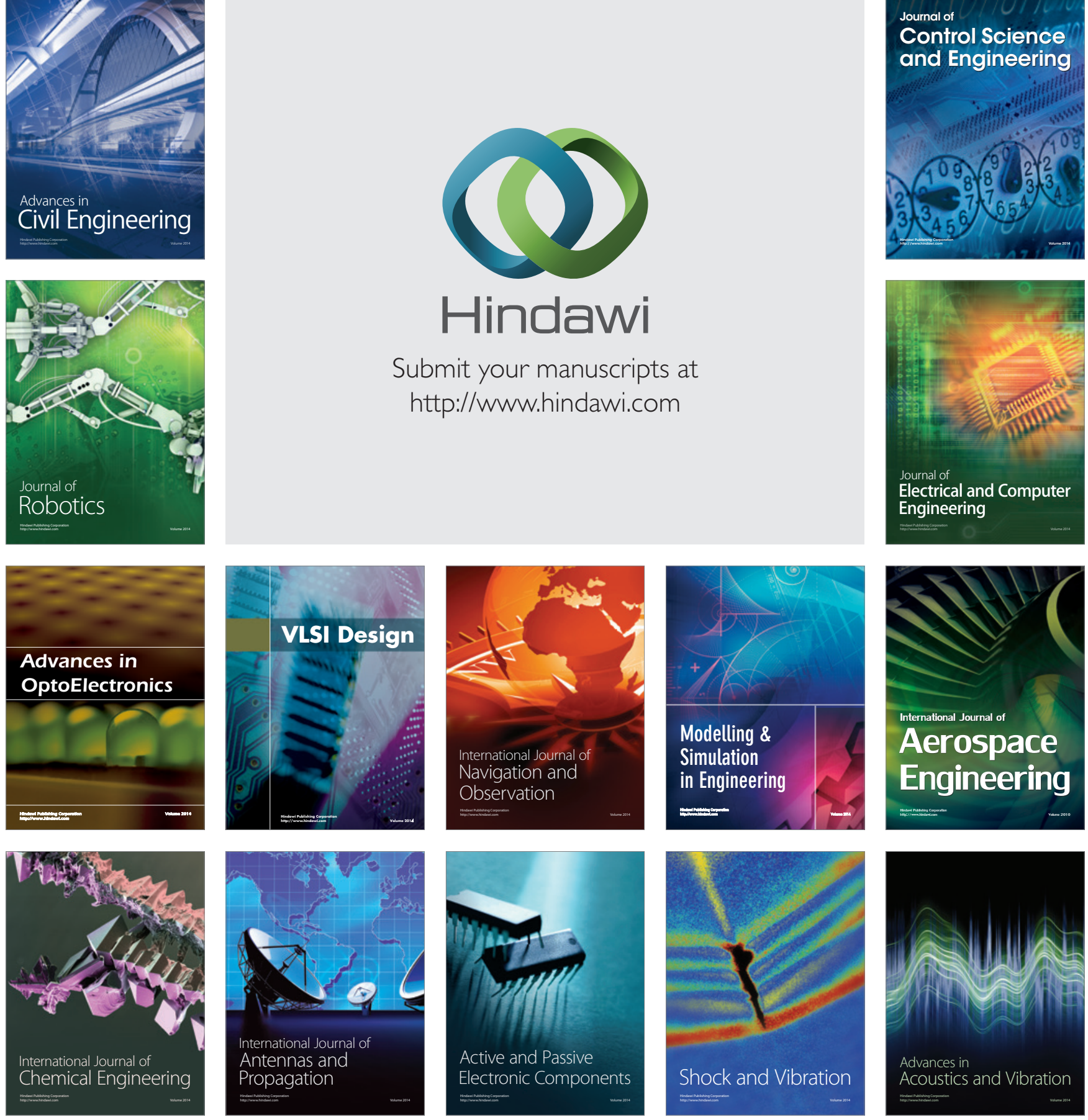